\title{
NOVEL LABORARORY TESTS IN ASSESSMENT OF LIVER FUNCTION IN ACUTE AND CHRONIC VIRAL LIVER DISEASES
}

\author{
Ludmila Vīksna*, Jāzeps Keišs**, Artūrs Sočṇevs*, Baiba Rozentāle**, Māra Pilmane*, \\ Natālija Sevastjanova**, Inita Buiḳe**, Agita Jēruma**, Elena Eglīte*, Kristīne Ābeltiṇa*, \\ and Valentīna Sondore**
}

* Rīga Stradinš University, Dzirciema iela 16, Rīga, LV-1007, LATVIA;
e-mail: Ludmila.Viksna @ rsu.Iv
** Infectology Centre of Latvia, Linezera iela 3, Rīga, LV-1006, LATVIA

Contributed by Ludmila Vīksna

\begin{abstract}
Liver biopsy in clinical practice has been widely used for the diagnosis and management of patients with liver diseases, particularly, with chronic liver diseases. However, liver biopsy is an invasive method with potential complications, sampling and interpretation errors. Therefore, noninvasive tests are being developed and introduced to replace liver biopsy. The aim of the present study was to identify the new noninvasive methods to be used for the assessment of liver structure and function, by use of the appropriate serum surrogate markers and to evaluate the clinical diagnostic and prognostic accuracy of these methods, including immunogenetic methods, in cases of acute and chronic liver diseases. The obtained data showed that serum markers of apoptosis (cytokeratin-18 neoepitope and citochrome c) and fibrosis (hyaluronic acid) should be included in viral and toxic liver damage management algorithms. The punctual identification of immunogenetic factors (HLA class II antigens) may prove to be useful in predicting disease evolution, and in guiding the appropriate therapy for patients with poor prognosis.
\end{abstract}

Key words: apoptosis, fibrosis, HLA class II antigens, liver diseases.

\section{INTRODUCTION}

The conventional liver function tests are often limited in quantifying hepatic function. Despite major advances in the diagnostics and therapy of liver diseases of different etiologies, the assessment of liver function continues to present a major clinical problem. Most liver function tests are not sufficiently specific and most of them do not accurately predict liver failure and outcome.

Liver biopsy in clinical practice has been widely used for the diagnosis and management of patients with liver diseases, and for treatment decision and assessment of treatment efficacy. In research, liver biopsy has provided a structural basis for an insight into the pathophysiology, contributing to a better understanding of liver disease mechanisms.

Liver biopsy is an invasive method, and there are potential adverse effects and complications. Certain precautions and means minimise the risks of adverse events. Biopsy conducted by a trained physician, use of only a limited number of passes and ultrasound guidance can significantly decrease the risk of complications, thereby enhancing the safety of biopsy (Bedossa and Carrat, 2009).

The main drawbacks (Regev et al., 2002; Rousselet et al., 2005; Bedossa, 2009; Colli and Fraquelli, 2009; Reddy and
Schiff, 2002) of liver biopsy as a diagnostic procedure lie in sampling and observation errors. Observer variation is a potential limitation of biopsy, which is related to the discordance between pathologists in biopsy interpretation.

The main alternatives to liver biopsy that have been developed in the past ten years are based on two very different concepts: serum markers and liver stiffness (Manning and Afdhal, 2008), which are both noninvasive procedures.

Biochemical marker combinations are being developed as alternatives to liver biopsy in patients with liver diseases, especially with chronic liver diseases. Noninvasive tests are being developed to replace liver biopsy, and thus avoid the risk of biopsy-related adverse events. Noninvasive tests also have the potential to avoid limitations of liver biopsy including the risk of sampling errors and inter- and intrapathologist variability.

Although clinicians already use surrogate markers as liver biopsy substitutes in their practices, offers are waiting for more valid tests (Mehta et al., 2009), especially for staging fibrosis and apoptosis identification and confirmation.

Fibrosis is not an autonomous feature, but rather a tissue lesion resulting from other pathologic mechanisms such as inflammatory, degenerative or dystrophic processes leading 
to, for example, hepatocellular carcinoma and portal hypertension.

The physiological process of apoptosis (programmed cell death) can be transformed into a pathological process, which can stimulate hepatic fibrosis, e.g. in hepatitis C, or can contribute to treatment failure (Schinoni et al., 2006). Over the last years, the importance of apoptosis for the pathogenesis of various diseases has been extensively investigated. Apoptosis is a Greek term that means ,the fall of the old leaves from the autumn trees". This term describes the process by which undesirable, damaged old cells are eliminated from multicellular organisms.

Apoptosis differs from cellular necrosis, because it is actively controlled, and membrane integrity is maintained, avoiding extravasation of intracellular material and an inflammatory response. In order to discover the mechanisms by which hepatitis viruses and other agents perpetuate in the liver, apoptosis in liver disorders should be investigated. Apoptosis is the first step in hepatic lesions, and fibrosis is the final response of hepatic stellate cells to this process. There may be a direct relationship between these two processes.

Apoptosis and cell necrosis can be differentiated by morphology. However, liver diseases are often accompanied by a combination of both processes, so there is mostly no clear borderline. Apoptosis assessment yet is not frequent in liver biopsy. However, several apoptosis biochemical markers in blood are available at present (cytochrome c, cytokeratin-18 neoepitopes etc.).

Fibrosis is a consequence of the necroinflammatory process. The process of fibrogenesis results in an increase in the extracellular matrix of: 1) collagen, 2) glycoproteins and 3) proteoglycans (e.g. hyaluronic acid).

Fibrotic status is usually assessed by liver biopsy, which has numerous disatvantages (Bottero et al., 2009), and several noninvasive methods have been developed for assessing fibrosis. However, the etiology of liver disease and the existence of co-morbidities affect the performance of noninvasive markers and cut-off values (Bottero et al., 2009).

Liver biopsy is currently the gold standard for assessment of liver fibrosis, yet it faces competition from non-invasive markers, which are easier to use, more acceptable to patients and repeatable over time. Biopsy samples are also usually too small to diagnose the disease accurately and diagnostic opinions often differ among pathologists (Rousselet et al., 2005). As a result, a morphological examination does not always provide an accurate diagnosis.

Recently, blood hyaluronic acid has been available for the assessment of liver fibrosis as a rapid and less invasive method.

The specific course of disease might be explained also by the diverse immunogenetic backgrounds of patients. The host's ability to react to viral antigens has often been associated with the human leukocyte antigen (HLA), mainly HLA class II antigens. Many studies suggest that the cellular im- mune response, e.g. to $\mathrm{HCV}$, particularly the $\mathrm{T}$ helper (Th) lymphocyte response, plays a crucial role. The cellreceptors recognise only peptides bound to HLA class II molecules. Polymorphisms due to amino acid substitutions at specific positions may intervene within the HLA class II molecule and interact with both the peptide and $\mathrm{T}$ cellreceptor; therefore, the HLA type characterising each individual may influence the subject's immune response to particular pathogens. Certain HLA alleles have been shown to influence the outcome of other chronic viral infections, and a few recent studies examined class II HLA alleles in the context of hepatitis $\mathrm{C}$ virus (HCV) clearance. The present study, which considers the relationship between HCV and HLA class II antigens from the locus DRB1* point of view, aimed to investigate whether differences of HLA class II antigens exist among HCV-infected patients with respect to healthy controls. The possibility that these antigens are associated with resistance or susceptibility to chronic HCV infection was also considered. The class HLA II human leukocyte antigens $(\mathrm{DRB} 1 *)$ are central to the host immune response and thus are ideal candidate genes to investigate for associations with HCV outcomes.

The aim of this study was to investigate whether human leukocyte antigen (HLA-DRB1) alleles are associated with the response to PEG-interferon+ Ribavirin (combined therapy) and Realdiron therapy in patients with chronic hepatitis C. Our aim was to also identify new non-invasive methods for the assessment of liver function in acute and chronic liver diseases and to evaluate the clinical diagnostic and prognostic accuracy of these methods, including immunogenetic methods.

\section{MATERIALS AND METHODS}

During apoptosis, a sequence of caspases (they all are proteases that cleave proteins at the aspartic acid residue) creates an expanding cascade of proteolytic activity which leads to digestion of structural proteins in the cytoplasm and generates e.g. apoptotic cytokeratin 18 (CK-18) neoepitopes.

To define the role of apoptosis processes in acute and chronic HBV and HCV infection development, the quantitative detection of serum CK-18 neoepitope was performed by using a noninvasive method for caspase-generated CK18 fragment determination (M30-Apoptosense ${ }^{\circledR}$, ELISA kit, PEVIVA, Sweden) in acute and chronic hepatitis patients. The study group consisted of 11 patients with acute hepatitis B, 14 with acute hepatitis C, 132 with chronic hepatitis C and, for comparison, in 23 patients with acute alcoholic hepatitis, all treated in the Infectology Centre of Latvia.

Mitochondrial pathway involvement in apoptosis process was evaluated by determining serum cytochrome c by „Human cytochrome c ELISA", Bender MedSystems (Austria) in 129 patients with chronic hepatitis $\mathrm{C}$, in 12 with acute hepatitis B, and in 29 patients with acute alcoholic hepatitis.

Serum hyaluronic acid (HA) as a potential marker of fibrosis evolution was measured by ELISA (Corgenix Inc., Colorado, USA) according to manufacturer's instructions in 16 
patients with acute hepatitis $\mathrm{B}$, in 9 with acute hepatitis $\mathrm{C}$, in 22 with acute alcoholic hepatitis, and in 132 patients with hronic hepatitis $\mathrm{C}$.

The study was conducted in compliance with the Helsinki Declaration, and Good Clinical Practice guidelines and local regulations, and was approved by the Ethics Committee of Rīga Stradiňš University (Latvia).

Diagnosis was based on modern immunochemical hepatitis marker assays and clinical, biochemical and morphological findings. Results were expressed as means \pm SE. For two group comparison the unpaired Student's t-test was used; $P \geq 0.05 \%$ was considered significant.

Liver tissue samples were taken from four patients, who died from acute hepatitis A during 2008. Immunhistochemical analysis of samples included determination of tissue degradation enzymes matrix matalloproteinases 2 (MMP2, AF902, goat, $1: 25$, RDSystems, UK), MMP9 (rabbit, 1 : 250, Santa Cruz Biotechnology, INC), MMP13 (mouse, sc81547,1 : 100, Santa Cruz Biotechnology, INC), natural antimicrobial peptides defensins 2 and 4 (AF2758, goat, 1 : 100, RDSystems, UK) and (sc-59496, mouse, 1 : 100, Santa Cruz Biotechnology, INC), inflammatory marker - tumour necrosis factor alfa (TNFi, ab9578, mouse, 1 : 100, abcam, UK), different interleukins - IL1i (sc-9983, mouse, 1 : 250, Santa Cruz Biotechnology, INC), IL6 (mouse, $1: 250$, Santa Cruz Biotechnology, INC), IL8 (goat, 1 : 100, Santa Cruz Biotechnology, INC), nuclear kappa factor (NKFbp105, ab7971, rabbit, 1 : 100, abcam, UK), and stress marker heat schock protein (Hsp70, ab5442, mouse, 1 : 100, abcam, UK), growth factors - hepatocyte growth factor (HGF, AF294NA, goat, 1 : 300, RD Systems, UK), insulin growth factor (IGF) (IGF, MAB291, goat, 1 : 50, RDSystems, UK), insulin growth factor receptor one (IGF1R, AF305NA, goat, $1: 100$, RD Systems, UK), and vascular endothelial growth factor (VEGF, 7273, 1 : 50, Dako, Cytomatin, Denmark), basal membrane components - collagen type IV (2233PCO, rabbit, 1 : 25, Euro-Diagnostica), laminin (2233PLA, rabbit, $1: 25$, Euro-Diagnostica), and fibronectin (A0245, rabbit, 1 : 100, Dako, Cytomatin, Denmark). IMH labelling was achieved using the standard streptavidin and biotin method (Guesdon et al., 1979). For apoptosis detection, terminal deoxynucleotidyl transferasemediated deoxyuridinetriphosphate nick end-labelling (TUNEL) using an in situ cell death detection kit (Roche Applied Science, Penzberg, Germany) was performed (Gavrieli et al., 1992). Haematoxylin and eosin were used for routine staining.

A total of 168 patients, divided into four groups, were enrolled in the immunogenomics study. Group A included 59 patients with HCV infection, treated with PEG-interferon + Ribavirin. Group B consisted of 45 patients with HCV infection and the same treatment regimen, but ineffective. Group C consisted of 30 patients with HCV infection (effective Realdiron therapy). Group D included 34 patients with HCV infection treated with Realdiron (non-responders). In addition, group E consisted of 100 healthy donors as a control group.
HLA typing low-resolution for HLA- DRB1* was performed by polymerase chain reaction (PCR) with amplification with sequence-specific primers (SSP). PCR products were separated on $3 \%$ agarose, the amplified bands were visualised, and the DRB1 type was deduced.

The distribution of HLA-DRB1* genes in all five patient groups (A, B,C,D and E controls) was compared using the chi-squared test with Yates' correction or Fisher's Exact test. Odd ratios (OR) were calculated according to the Woolf's formula. All reported level of significance of $P$ values was 0.05 .

\section{RESULTS}

There was a very high serum level of CK-18 neoepitope in patients with acute hepatitis B $(1362.3 \pm 108.9 \mathrm{U} / \mathrm{L})$, which was higher than in patients with alcoholic hepatitis (1003.9 $\pm 104.3 \mathrm{U} / \mathrm{L} ; 0.02<P<0.05)$. CK-18 neoepitope concentration in acute hepatitis $\mathrm{C}(712.2 \pm 124.4 \mathrm{U} / \mathrm{L})$ and chronic hepatitis $\mathrm{C}(232.3 \pm 15.8 \mathrm{U} / \mathrm{L} ; 0.001<P<0.01)$ was significantly lower (Table 1 ). About $1 / 3$ of chronic hepatitis $C$ patients had normal serum ALT activity, but elevated serum CK-18 neoepitope concentration.

While cytochrome c normally is not detectable in serum, then in $47.45 \%$ of patients with chronic hepatitis $\mathrm{C}$ the level of this apoptosis indicator was increased $(0.29 \pm 0.05$ $\mathrm{ng} / \mathrm{ml}$ ) (see Table 1). Serum concentration of cytochrome C was even higher in acute hepatitites of viral and toxic etiology.

A very high serum concentration of HA was found in patients with acute alcoholic hepatitis (1015.50 \pm 58.83 $\mathrm{ng} / \mathrm{ml})$. Serum HA level was significantly higher in acute hepatitis $\mathrm{B}(228.13 \pm 51.71 \mathrm{ng} / \mathrm{ml})$ than in acute hepatitis C $(58.33 \pm 27.22 \mathrm{ng} / \mathrm{ml}, P<0.001)$ patients. The level of serum HA in patients with chronic hepatitis was $103.82 \pm$ $15.47 \mathrm{ng} / \mathrm{ml}$ (Table 2).

Preliminary results of liver tissue examination in hepatitis A showed disorganised structure of liver lobuli with various size of binucleated hepatocytes. Fibrosis was accompanied by necrotisation, inflammation and steatodystrophy. Re-

Table 1

LEVEL OF APOPTOSIS MARKERS IN SERUM FROM PATIENTS WITH ACUTE AND CHRONIC LIVER DISEASES

\begin{tabular}{l|c|c}
\hline \multicolumn{1}{c|}{ Patients } & $\begin{array}{c}\text { Cytokeratin-18 } \\
\mathrm{U} / \mathrm{L} \\
(\text { mean } \pm \mathrm{SE})\end{array}$ & $\begin{array}{c}\text { Cytochrome c } \\
\mathrm{ng} / \mathrm{ml} \\
(\mathrm{mean} \pm \mathrm{SE})\end{array}$ \\
\hline Acute hepatitis B & $\begin{array}{c}1362.3 \pm 108.9 \\
(\mathrm{n}=11)\end{array}$ & $\begin{array}{c}1.52 \pm 1.14 \\
(\mathrm{n}=14)\end{array}$ \\
Acute hepatitis C & $712.2 \pm 124.4$ & $3.15 \pm 1.84$ \\
& $(\mathrm{n}=14)$ & $(\mathrm{n}=3)$ \\
Chronic hepatitis C & $232.3 \pm 15.8$ & $0.29 \pm 0.05$ \\
& $(\mathrm{n}=132)$ & $(\mathrm{n}=129)$ \\
Acute alcoholic hepatitis & $1003.9 \pm 104.3$ & $0.59 \pm 0.19$ \\
& $(\mathrm{n}=23)$ & $(\mathrm{n}=58)$
\end{tabular}

Reference intervals for: Cytokeratin-18 - 47.1-103.9 U/L; Cytochrome c -0 . 
SERUM HYALURONIC ACID IN PATIENTS WITH ACUTE AND CHRONIC LIVER DISEASES

\begin{tabular}{l|c|c}
\hline \multicolumn{1}{c|}{ Patient group } & Number of patients & $\begin{array}{c}\text { Hyaluronic acid } \\
\mathrm{ng} / \mathrm{ml} \\
\text { mean } \pm \text { SE }\end{array}$ \\
\hline Acute hepatitis B & 16 & $228.13 \pm 1.71$ \\
Acute hepatitis C & 9 & $58.33 \pm 27.22$ \\
Chronic hepatitis C & 132 & $103.82 \pm 15.47$ \\
Acute alcoholic hepatitis & 22 & $1015.50 \pm 58.83$
\end{tabular}

Reference interval: $0-75 \mathrm{ng} / \mathrm{ml}$

garding MMP, MMP9 showed abundant expression, MMP13 variable, and MMP2 was not recorded. Inflammatory cells of two patients expressed TNF $\alpha$. Of IL, the most expressed was IL6, while levels of IL1 $\alpha$ and IL8 were lower. All hepatocytes demonstrated Hsp70, while NKFbp105 was seen only in one case. Among antimicrobial peptides only defensin 2 was synthesised in hepatocytes. A few to moderate number of hepatocytes and inflammatory cells were affected by apoptosis. HGF was observed in two patients, while ING1R was not found, despite the rich presence of IGF. The endotheliocytes of only one patient expressed VEGF. Structure of basal membranes was disorganised, with fibronectin only in the wall of the biggest blood vessels. No laminin, but rich collagen IV immunoreactivity demonstrated connective tissue fiber network in the liver.

In the present study we defined HLA-DRB1 alleles associated with $\mathrm{HCV}$ risk among patients with $\mathrm{HCV}$ infection and a healthy control group in Latvia. Some differences in the strength of these markers are presented in Table 3.

The highest frequency among patients with HCV infection was observed for the HLA-DRB $1 * 07$ allele $(\mathrm{OR}=7.0, P<$ $0.0001)$, HLA-DRB $1 * 03(\mathrm{OR}=1.95, P<0.035)$ and HLA-DRB $1 * 05(\mathrm{OR}=1.66, P<0.026)$; and the lowest frequency for DRB1*06, $(\mathrm{OR}=0.56, P<0.034)$ and DRB1 $* 15$ alleles $(\mathrm{OR}=0.59, P<0.020)$.

Table 4 shows the association with different alleles of HLA class II genes with HCV infection and therapy. One hun-
THE FREQUENCIES OF DEFINED DRB1* ALLELES IN HCV PATIENTS AND CONTROLS

\begin{tabular}{l|c|c|c|c}
\hline $\begin{array}{c}\text { Alleles } \\
\text { DRB1* }\end{array}$ & $\begin{array}{c}\text { HCV } \\
(\mathrm{n}=336)\end{array}$ & $\begin{array}{c}\text { Controls } \\
(\mathrm{n}=200)\end{array}$ & Odds Ratio & $P$ \\
\hline$* 01$ & 48 & 31 & 0.91 & $<0.701 * *$ \\
$* 15$ & 49 & 45 & $\mathbf{0 . 5 9}$ & $<\mathbf{0 . 0 2 0}$ \\
$* 03$ & 43 & 14 & $\mathbf{1 . 9 5}$ & $<\mathbf{0 . 0 3 5}$ \\
$* 04$ & 39 & 23 & 1.01 & $<0.970 * *$ \\
$* 05$ & 83 & 33 & $\mathbf{1 . 6 6}$ & $<\mathbf{0 . 0 2 6}$ \\
$* 06$ & 29 & 28 & 0.56 & $<0.034$ \\
$* 07$ & 42 & 4 & $\mathbf{7 . 0}$ & $<\mathbf{0 . 0 0 0}$ \\
$* 08$ & 3 & 14 & $\mathbf{0 . 1 2}$ & $<\mathbf{0 . 0 0 0}$ \\
$* 09$ & 0 & 2 & - & - \\
$* 10$ & 0 & 5 & - & - \\
\hline
\end{tabular}

** Cornfield not accurate. Extract limits preferred.

In bold, face type highlights statistically significant associations for patients vs controls; $P$, probability (l-p)* $100 \%$; OR, odds ratio; n, number of haplotypes (eg, 336 alleles from 168 individuals). Nature of valve lesions was not reported on two patients.

dred and four patients received PEG-interferon + Ribavirin therapy. Fifty-nine patients were characterised as responders, and the remaining 45 as non-responders. Sixty-four patients received Realdiron therapy. Thirty patients were characterised as responders, and the remaining 34 as nonresponders. All individuals in the study were genotyped for HLA class II DRB1* alleles.

The HLA-DRB1*06; HLA-DRB1*04 Major Histocompatibility class II allele is significantly associated with a beneficial response to PEG interferon + Ribavirin therapy in patients $(\mathrm{OR}=4.29, P<0.003$; OR $=1.97, P<0.014)$. Our results therefore provide evidence that HLA- DRB $1 * 06$ and HLA- DRB $1 * 04$ presence is an important additional factor for predicting a long-term response to PEG-interferon $+\mathrm{Ri}$ bavirin therapy in chronic hepatitis $\mathrm{C}$.

The results of class II HLA distribution in HCV positive patients are listed in Table 4.

Table 4

ASSOCIATION OF ALLELES OF HLA CLASS II GENES WITH HCV INFECTION AND THERAPY

\begin{tabular}{|c|c|c|c|c|c|c|c|}
\hline DRB $1 *$ alleles & $* 01$ & $* 15$ & $* 03$ & $* 04$ & $* 05$ & $* 06$ & $* 07$ \\
\hline $\begin{array}{l}\text { Total patient number } \\
\mathrm{n}=168\end{array}$ & 0.18 & $0.59 /(0.020)$ & 1.95/(0.035) & & $1.66 /(0.026)$ & $0.56 /(0.034)$ & $7.0 /(0.000)$ \\
\hline $\begin{array}{l}\text { Effective PEG INF+ Ribavirin therapy } \\
\mathrm{n}=59\end{array}$ & 0.14 & 0.14 & 0.13 & 1.97/0.014 & 0.21 & $4.29 /(0.003)$ & 0.03 \\
\hline $\begin{array}{l}\text { Noneffective PEG INF+ Ribavirin therapy } \\
\mathrm{n}=45\end{array}$ & 0.16 & 0.16 & 0.12 & 0.08 & $0.62 / 0.013$ & 0.06 & $0.18 / 0.005$ \\
\hline $\begin{array}{l}\text { Noneffective Realdiron therapy } \\
\mathrm{n}=34\end{array}$ & 0.09 & 0.16 & 0.13 & $0.53 / 0.065$ & 0.77 & 0.74 & 1.15 \\
\hline Control subjects & 0.16 & 0.23 & 0.07 & 0.12 & 0.17 & 0.15 & 0.02 \\
\hline
\end{tabular}

$\mathrm{n}=100$

In bold, face type highlights statistically significant associations for patients' vs controls; gf, gene frequency; $P$, probability; OR, odds ratio; and value are reported only for significant associations $(P<0.05)$; n, number of haplotypes (e.g., 336 alleles from 168 individuals). 
Among group $\mathrm{C}$ and $\mathrm{D}$ patients, HLA-DRB1*01 was demonstrated to be significantly associated with a beneficial response to Realdiron therapy in chronic hepatitis $\mathrm{C}$ patients $(\mathrm{OR}=2.58, P<0.071)$. In group D, HLA-DRB $1 * 04,(\mathrm{OR}$ $=0.53, P<0.065)$ was found to be an indicator of nonresponders to Realdiron therapy. In both $\mathrm{C}$ and $\mathrm{D}$ groups, the frequency of the remaining HLA antigens was of minor importance.

\section{DISCUSSION}

Liver biopsy is not always possible or reproducible, it cannot be performed frequently and is a costly invasive procedure with a certain, although low, risk of serious complications. Histological examination of the liver does not provide information about the dynamics of hepatic fibrogenesis, and liver biopsy provides only static information about the fibrotic process. Non-invasive markers that reflect fibroproliferative activity in the liver and the treatment response would be preferable. Serum hyaluronic acid has been identified now as a potential marker of fibrosis evolution.

The clinical benefit of the existing markers may be limited by the etiology or stage of disease. Hyaluronate can be used as specific marker to detect liver fibrosis (Afdhal and Nunes, 2004) and has been found to correlate with severity of the disease (Lackner et al., 2005). Kawamoto et al. (2006) suggested that hyaluronate could be used to assess severe liver fibrosis or cirrhosis, but that it would be difficult to assess liver fibrosis at its early stage. According to Suzuki et al. (2005), hyaluronic acid is reported to have a high diagnostic performance in assessing the severity of hepatic fibrosis in patients with alcoholic liver disease. Our observations are consistent with the above reports, particularly, in the case of acute alcoholic hepatitis, when the level of hyaluronic acid in blood serum was very high (see Table 2).

The performed parallel histological investigations of liver biopsies from patients with chronic hepatitis $\mathrm{C}$ illustrated the heterogeneity of hepatic fibrosis degree. Serum HA levels did not significntly correlate with the degree of hepatic fibrosis found in these patients. HA may be a marker of hepatic fibrosis progression. In chronic liver diseases, serial HA levels have been advocated as a means to monitor disease progression and to limit the need for follow-up liver biopsy.

The levels of the main apoptosis markers (cytokeratin-18 neoepitope, cytochrome c) observed in serum (Table 1) suggest significant involvement of apoptosis processes (including the mitochondrial path) in pathogenesis of acute hepatitis, independently of etiology. This presumption is confirmed by high level of apoptosis markers in serum (see Table 1). The delineation of the signal path that mediates apoptosis changed the paradigms of understanding in many liver diseases (Schattenberg et al., 2006). Apoptosis is a normal physiological response to many chemical, physical and biological stimuli. Mitochondria and cell surface receptors mediate the two main pathways of apoptosis (Reed, 2000). Hypoxia has been shown to promote apoptosis (Holmgren et al., 1995). Thus, the treatment of ischemic injury remains one of the most challenging areas of hepato- logy today, because apoptosis is closely involved in the process of liver disease progression.

Apoptosis defines a type of cell death distinct from the more conventional necrotic death on the basis of characteristic morphological features. Although these descriptions and distinctions are useful, there is a great deal of overlap between apoptosis and necrosis in morphological features and biochemical events. Indeed, apoptosis is frequently followed by secondary necrosis of cells, especially, if there is failure of clearance or ingestion of apoptotic bodies (Bennett, 2002).

Abundant expression of HGF characterises hepatitis A affected liver with less distinct fibrosis and apoptosis. The dominating MMP in VAH liver is MMP9, while MMP13 shows only individual variations. Hepatitis A also possesses the distinct IL6 expression in the acute stage, while seemingly individual variations affect IL1 $\alpha$ and IL8 appearance. The presence of NKFbp105 in only one patient whose liver did not show collgenases and other inflammatory markers possibly is related to the stimulatory effect of this transcriptional factor on proliferation. Rich expression of Hsp70 and defensin 2 in hepatitis A indicates the ability of hepatocytes to still produce antimicrobial peptides under the serious cellular stress.

One of our study aims was to confirm the influence of HLA class II antigens on the progression of HCV infection and to assess a possible relationship between these antigens and different therapy. For this purpose we used the PCR-SSP test, which permits the routine determination of HLA class II distributions. We confirmed that the frequency of HLA-DRB $1 * 06$ and *04 was significantly higher in Group A HCV infection patients $(\mathrm{OR}=0.56 / 0.034)$ and in HCV-positive patients (group A) than in those (4.29/0.003) with progression of $\mathrm{HCV}$ infection $(P<0.05)$. Alleles HLA-DRB $1 * 07$ and HLA-DRB $1 * 05$ were demonstrated in a general group of $\mathrm{HCV}$-infected patients and a similar proportion of HLA-DRB $1 * 07$ + was found among non-responders to PEG-interferon + Ribavirin therapy.

In the two anti-HCV-positive patient groups, a correlation was found between specific HLA antigens and the extent of liver damage. Among the host-related factors that have an important role in determining the outcome of $\mathrm{HCV}$ infection, some HLA class II antigens appear crucial for resolution or progression of hepatitis $\mathrm{C}$. These new methods have been more widely used for the management of chronic hepatitis, irrespective of the specific etiology.

Accumulation of evidence regarding the limitations of biopsy has led some to suggest that non-invasive markers should replace biopsy as the initial method for disease staging. But further research is needed to evaluate the long-term effectiveness of the these strategies before a global recommendation can be made (Mehta et al., 2009). It is widely appreciated that substantial error has been observed when biopsy specimens have been compared to the full liver (Colloredo et al., 2003).

There are several advantages in using non-invasive markers: they can be used to accurately define an appropriate time 
for treatment initiation, they can help monitoring and assess the therapeutic efficacy of antiviral treatment in cases of liver fibrosis and cirrhosis, etc., and they are crucial in evaluating the performance of non-invasive markers in liver fibrosis and apoptosis diagnosis in HAV, HBV, HCV, HIV-infected patients.

In summary, apoptosis evaluation by the CK-18 neoepitope level estimation should be included in the hepatitis virus infection and toxic liver damage management algorithm. Apoptosis, not only necrosis, is essentially involved in liver damage development mechanisms in acute and chronic $\mathrm{HAV}, \mathrm{HBV}$ and HCV infection. Monitoring of the serum apoptotic CK-18 neoepitope level might help to estimate liver diseases therapy efficacy and open new approaches to apoptosis therapeutic regulation.

While in alcoholic hepatitis apoptosis may be a principal cause of cell death, in acute hepatitis B cell death can be associated with both cell apoptosis and cell necrosis.

As the fibrogenic process is dynamic, serum hyaluronic acid levels may reflect fibrogenesis rather than developed and formed fibrosis. Circulating HA measurement has been proposed for operative monitoring of fibrotic lesion dynamics in acute and chronic cases of liver damages.

The punctual identification of immunogenetic factors may prove to be useful in predicting disease evolution, in guiding the appropriate therapy for patients with poor prognosis, and in encouraging the development of new therapeutic strategies.

\section{ACKNOWLEDGEMENTS}

The work was supported by the National Research Programme in Medicine 2006-2009 project No. 10. „,Bloodtransmissive viral infections affecting life expectancy: viral persistence in human organism and paradigms of diagnostics and treatment".

\section{REFERENCES}

Afdhal, N.H., Nunes, D. (2004). Evaluation of liver fibrosis: A concise rerview. Amer. J. Gastroenterol., 99, 1160-1174.

Bedossa, P. (2009). Assessment of hepatitis C: Non-invasive fibrosis markers and/or liver biopsy. Liver Internat., 29 (S.1), 19-22.

Bedossa, P., Carrat, F. (2009). Liver biopsy: The best, not the gold standard. J. Hepatology, 50(1), 1-3.
Bennett, M.R. (2002). Apoptosis in the cardiovascular system. Heart, 87(5), 480-487.

Bottero, J., Lacombe, K., Guéchot, J., Serfaty, L., Miailhes, P., Bonnard, P., Wendum, D., Molina, J.-M., Lascoux-Combe, C., Girard, P.-M. (2009). Performance of 11 biomarkers for liver fibrosis assessment in HIV/HBV co-infected patients. J. Hepatol., 50(6), 1074-1083.

Colli, A., Fraquelli, M. (2009). What is the actual role of diagnosis and how to assess it? J. Hepatol., 50(4), 827-829.

Colloredo, G., Guido, M., Sonzogni, A. \& Leandro, G. (2003). Impact of liver biopsy size on histological evaluation of chronic viral hepatitis: The smaller the sample, the milder the disease. J. Hepatology, 39, 239-244.

Gavrieli, Y., Sherman, Y., Ben-Sasson, S.A. (1992). Identification of programmed cell death in situ via specific labeling of nuclear DNA fragmentation. J. Cell Biol., 119, 493-501.

Guesdon, J.L., Ternynsk, T., Avrameas, S. (1979). The use of avidin-biotin interaction in immunoenzymatic techniques. J. Histochem. Cytochem., 27, 1131-1139.

Holmgren, L., O’Reilly, M.S., Folkman, J. (1995). Dormancy of micrometastases: Balanced proliferation and apoptosis in the presence of angiogenesis suppression. Nat. Med., 1, 149-153.

Kawamoto, M., Mizuquchi, T., Katsuramaki, T., Nagayama, M., Oshima, H., Kawasaki, H., Nobuoka, T., Kimura, Y., Hirata, K. (2006). Assessment of liver fibrosis by non invasive method of transient elastography and biochemical markers. World J. Gastroenterol., 12(27), 4325-4330.

Lackner, C., Struber, G., Liegl, B., Leibl, S., Ofner, P., Bankuti, C., Baner, B., Stanber, R.E. (2005). Comparison and validation of simple noninvasive tests for predication of fibrosis in chronic hepatitis C. Hepatology, 100, 868-873.

Manning, D.S., Afdhal, N.H. (2008). Diagnosis and quantitation of fibrosis. Gastroenterology, 134, 960-974.

Mehta, S.H., Lau, B., Afdol, N.H., Thomas, D.L. (2009). Exceeding the limits of liver histology markers. J. Hepatology, 50(1), 36-41.

Reed, J.C. (2000). Warner-Lambent/Parke-Davis awards lecture: Mechanisms of apoptosis. Amer. J. Pathol., 157, 1415-1430.

Regev, A., Berho, M., Jeffers, L.Z., Milikowski, C., Molina, E.G., Pyrsopoulos, N.T., Feng Z., Reddy, K.R., Schiff, E.R. (2002). Sampling error and intraobserver variation in liver biopsy in patients with chronic $\mathrm{HCV}$ infection. Amer. J. Gastroenterol., 97, 2614-2618.

Rousselet, M.C., Michalak, S., Dupre, F., Croué, A., Bedossa, P., Saint-André, J.P., Cales, P. (2005). Sources of variability in histological scoring of chronic viral hepatitis. Hepatology, 41, 257-264.

Schattenbeg, J.M., Galle, P.R., Schuchmann, M. (2006). Apoptosis in liver disease. Liver Internat., 26(8), 904-911.

Schinoni, M.I., Paranį, R., Cavalcante, D. (2006). Apoptosis and progression of hepatic fibrosis in hepatitis C patients. Braz. J. Infect. Dis., 10(2), 117-121.

Suzuki, A., Mendes, F., Lindor, K. (2005). Diagnostic model of esophageal varices in alcoholic liver disease. Eur. J. Gastroenterol. Hepatol., 17(3), 307-309.

\section{JAUNAS ASIN̦U IZMEKLĒŠANAS METODES AKNU FUNKCIJAS NOVĒRTĒŠANAI AKŪTU UN HRONISKU AKNU VĪRUSU SLIMĪBU GADİJUMĀ}

Klīniskajā praksē plaši tiek izmantota aknu biopsija aknu slimību, īpaši hronisko, diagnostikā. Taču punkcijas biopsija ir invazīva metode, pacientam iespējamas komplikācijas, nav izslēgtas neveiksmīgas aknu audu paraugu paņemšanas vietas un aknu audu morfoloǵiskās izpētes rezultātu interpretācijas kḷūdas. Pētījuma mērḳis bija identificēt jaunas, neinvazīvas metodes aknu struktūras un funkcijas novērtēšanai akūtu un hronisku aknu slimību gadījumos, izmantojot atbilstošus seruma marķierus, kā arī novērtēt šo metožu (ieskaitot imūnǵenētiskās) diagnostisko un prognostisko precizitāti un nozīmību. Iegūtie rezultāti parādīja, ka apoptozes (citokeratīna-18 neoepitops, citohroms c) un fibrozes (hialuronskābe) marḳieru kvantitatīva noteikšana asins serumā jāiekḷauj virusālo un toksisko aknu bojājumu menedžmenta algoritmā. Precīza imūnǵenētisko faktoru (HLA II klases antigēnu) identifikācija var būt visai noderīga aknu slimību gaitas prognozēšanā un to adekvātas terapijas izvēlē. 